\title{
Nedtrykt af negative nyheder: Effekten af positive og negative tv-nyheder på seernes humør, hukommelse og lyst til at se nyheder
}

AF MORTEN SKOVSGAARD OG PERNILLE FRANTZ SøBERG

\section{Resumé}

I adskillige år er det blevet debatteret, hvorvidt nyhedernes negative fokus har konsekvenser for borgerne, og om det i sidste ende får flere til at vende ryggen til nyhederne. Vores viden om effekterne af positive og negative nyheder er dog begrænset, og derfor undersøges det i denne artikel, hvordan henholdsvis positive og negative tv-nyheder påvirker seernes humør, hukommelse af information fra indslaget og lyst til at se yderligere tvnyheder. Det gør vi i et survey-eksperiment $(\mathrm{N}=204)$, hvor tre grupper så enten et originalt indslag eller det samme indslag klippet med henholdsvis et positivt eller et negativt fokus, mens en fjerde gruppe ikke så noget indslag og fungerede som kontrolgruppe. Eksperimentet viser, at folk, der så et indslag med negativt fokus, kom i signifikant dårligere humør end dem, der så et positivt indslag, eller dem, der ikke så noget indslag. Undersøgelsen viser ingen effekter af et positivt kontra et negativt fokus, når det kommer til at huske information fra indslaget eller lyst til at se yderligere tv-nyheder.

\section{Introduktion}

Rollen som samfundets kritiske vagthund er en vigtig del af journalisters selvforståelse (Skovsgaard et al., 2012; Weaver \& Willnat, 2012), og som en konsekvens har en stor del af journa- 
listikken en kritisk vinkel og fokuserer på problemer og konflikt. På forskellige områder som politik, økonomi og kriminalitet viser undersøgelser, at journalisterne fokuserer på negative og konfliktfyldte oplysninger og begivenheder, når de producerer nyheder, også selvom mere positive oplysninger og begivenheder er tilgængelige (se fx Elmelund-Præstekær \& Svensson, 2014; Soroka, 2014). Samtidig viser en undersøgelse, at 76 procent af danskerne mener, at medierne fokuserer for meget på kriser og konflikter (Hede et al., 2009).

Danskernes reaktioner på den negative tendens i journalistikken har også vakt bekymring på chefkontorerne på de danske nyhedsmedier. Nyhedsdirektør i Danmarks Radio, Ulrik Haagerup, beskriver mediernes præference for problemer som en væsentlig årsag til pressens krise i den vestlige verden. Den traditionelle journalistik"... fastholder, at god journalistik handler om at dramatisere, udstille konflikter, finde skurke ogynke ofre," og det får ifølge Haagerup mediebrugeren til at vende ryggen til journalistikken (Haagerup, 2012:15). Det kritiske fokus risikerer altså at have negative konsekvenser for demokratiet, selvom netop det kritiske fokus oprindeligt var en del af rollen som samfundets vagthund, der skulle sikre et sundt demokrati (fx McQuail, 2005).

For at bidrage til debatten om, hvordan nyhedsbrugerne bliver påvirket af henholdsvis negative og positive nyhedshistorier, undersøger vi i denne artikel tre mulige effekter af henholdsvis negative og positive nyhedshistorier - nemlig i hvor høj grad nyhedsbrugerens humør påvirkes, i hvor høj grad nyhedsbrugeren kan huske information fra nyhedshistorien, og i hvor høj grad nyhedsbrugeren får lyst til at se flere nyheder. Litteraturen peger på, at det negative generelt har stærkere effekter på mennesker end det positive (Baumeister et al., 2001). På den baggrund kan man forvente, at de negative nyhedshistorier har den største effekt på nyhedsbrugerens humør, men også på hans eller hendes hukommelse af information fra nyhedshistorien samt på hans eller hendes lyst til at se flere nyheder.

For at undersøge disse spørgsmål har vi i et eksperiment præsenteret deltagerne for et tv-indslag om kommunernes brug af et tilbud om efteruddannelse af deres personale i at opdage børn, der har været udsat for vold eller seksuelle overgreb. Nyhedshistorien blev klippet om til tre forskelligt vinklede versioner: den 
originale, en positiv og en negativ. Ved at holde historien konstant og kun ændre graden af negativitet og positivitet kan vi undersøge effekterne af netop dette aspekt af historien.

I det følgende vil vi først uddybe journalisternes kritiske og negative fokus samt de mulige effekter af negative over for positive historier. Dernæst vil vi præsentere metoden bag eksperimentet mere detaljeret, inden vi til slut beskriver og diskuterer resultaterne.

\section{Negativitet i nyhederne}

Journalister kritiseres jævnligt for at fremme et negativt billede af verden ved at fokusere overdrevet på negative begivenheder og nyheder. En række bøger og artikler - primært amerikanske og britiske - har kritiseret journalistikkens hang til at udvælge og producere negative nyheder (fx Fallows, 1996; Patterson 1994; Sabato, 1991). En undersøgelse af tonen på forsiderne af Ekstra Bladet, BT, Berlingske, Politiken og Jyllands-Posten viste da også, at 34 ud af 55 historier var negativt vinklede, mens kun 10 historier var positivt vinklede. 11 historier blev vurderet som neutrale (Hylleberg et. al., 2012: 26-27). En noget større undersøgelse af DR og TV 2's nyhedsdækning af udenlandsstof peger også på, at det negative er i fokus. Kriminalitet, ulykker, krig, borgerkrig, sygdom, terror og katastrofer fyldte mellem 47-61 procent af udlandsdækningen i perioden 2003-2004. Mellem 76-86 procent af alle udlandsnyhederne var baseret på nyhedskriteriet konflikt (Kabel, 2005: 31).

En udfordring i den slags undersøgelser er, at vi ikke har nogen målestok for den verden, journalisterne forsøger at afspejle. Det gør det svært at afgøre, om det er journalisterne, der har en overdrevet tendens til at udvælge og producere negative historier, eller om det univers af information, de vælger fra, også er mere negativt end positivt. Den udfordring er dog blevet taget op i flere studier, hvor journalisternes historier holdes op mod en målestok, der kan sige noget om, hvorvidt tendensen til negative nyheder stammer fra journalisternes måde at udvælge og bearbejde nyheder på. En undersøgelse sammenlignede en komplet database over registrerede forbrydelser i den amerikanske 
by Bloomington med mediedækningen af kriminalitet i byen. Analysen viste, at voldelige forbrydelser var overrepræsenteret $\mathrm{i}$ mediedækningen i forhold til i kriminalitetsstatistikkerne i alle de fem år, undersøgelsen dækkede (Soroka, 2014). Konklusionen blev bekræftet i et studie, hvor positive eller negative bevægelser i $ø$ konomiske indikatorer blev sammenlignet med mediedækningen af økonomi i USA, Storbritannien og Canada. I alle tre lande var mediedækningen mere negativ end udviklingen i de økonomiske indikatorer, hvilket pegede på journalisternes tendens til at vælge negative nyheder (ibid.; se Baum \& Groeling, 2010 for et lignende design og samme konklusion).

I en dansk kontekst viste en analyse af afslutningsdebatterne i folketingsvalgkampene fra 2005 til 2011, at andelen af negative budskaber blandt politikerne var på 38 procent, mens mediernes udvalg af negative citater i dækningen af afslutningsdebatten udgjorde en andel på 57 procent. Også denne undersøgelse bekræftede, at journalisterne foretrækker de negative budskaber frem for de positive (Elmelund-Præstekær \& Svensson, 2013).

Journalisternes fokus på negative begivenheder gør det interessant at undersøge, hvordan henholdsvis negative og positive nyheder påvirker modtagerne. Især fordi selv i en situation, hvor der var balance mellem de negative og positive nyheder, ville de negative nyheder have tendens til at fylde mere hos modtagerne end de positive nyheder (Knoop, 2012:61). Denne negativitetsbias er velbelyst (se Baumeister et al., 2001; Sorokoa 2014 for et overblik) og bakkes op af et evolutionsbiologisk argument. Gennem evolutionens historie ville organismer, der reagerede stærkt på negative eller farlige ting, være mere tilbøjelige til at overleve trusler og dermed have større chance for at videregive deres gener. En person, der ignorerede mulighederne for et muligt positivt udfald, kunne senere fortryde, at han eller hun gik glip af muligheden for at opleve noget glædeligt, men følelsen af fortrydelse ville sjældent være forfærdelig og næppe livstruende. En person, der derimod ignorerede mulighederne for en negativ begivenhed, for eksempel fare, kunne potentielt ende lemlæstet eller død (Baumeister et al., 2001; Knoop, 2012).

Selvom negative nyheder handler om - snarere end fører til død eller lemlæstelse, er argumentet, at adfærd er så indlejret i menneskets natur, at den også smitter af på den måde, hvorpå 
vi påvirkes af negative og positive informationer på, så negative informationer vejer tungere. Soroka har vist dette i et studie af, hvordan individer reagerede på henholdsvis positive og negative nyheder om økonomi (2006). Negative nyheder om økonomien fik den økonomiske pessimisme blandt befolkningen til at stige mere, end positive nyheder fik optimismen til at stige (Soroka, 2006: 381).

\section{Negative og positive nyheders effekt på humør}

Modtagerens humør er et af de aspekter, der kan forventes at blive påvirket af de negative nyheder. Undersøgelser har vist, at negative tv-billeder skaber større følelsesmæssige reaktioner hos seeren end positive (Reeves et al., 1989), og at journalisters negative fortællemåde og vinkling påvirker seeren stærkt følelsesmæssigt (Peterson \& Sten, 2009:6-7).

I et eksperiment viste Gyldensted (2011), at en original, negativ nyhed reducerede positive følelser og øgede negative følelser signifikant hos læseren. Hun undersøgte samtidig effekten af fem forskellige positive udgaver af den samme historie, men fandt hverken signifikante effekter på positive eller negative følelser. At de positive historier ikke havde nogen effekt, kan dog muligvis forklares af undersøgelsesdesignet, hvor deltagerne først blev eksponeret for den originale, negative nyhed og derefter for en af de fem positive udgaver af den samme nyhed. Det betød, at når deltagerne læste den positive udgave, havde de allerede læst den samme nyhed i en negativ udgave, hvilket gør det sværere at få en umiddelbar følelsesmæssig reaktion på nyheden. Alligevel kan resultaterne indikere, at negative historier har større effekter på humøret end positive historier.

På den baggrund er vores første forventninger:

H1a: En positiv nyhed vil resultere i mere positivt humør end en negativ nyhed. $\mathrm{H} 1 \mathrm{~b}$ : En negativ nyhed vil resultere i mere negativt humør end en positiv nyhed. H1c: En negativ nyhed vil have en større effekt på humøret end en positiv nyhed.

De negative og positive nyheder kan også forventes at have en effekt på, i hvilken grad modtageren kan huske væsentlige oplysninger fra nyhedshistorien. De samme evolutionspsykologiske 
mekanismer, som gør os opmærksomme på fare, trækker også vores opmærksomhed mod negativ information (Reeves et al., 1989; Newhagen \& Reeves, 1992: 25-26). Undersøgelser har vist, at negative budskaber bliver opfattet som vigtigere end positive (Meyerowitz \& Chaiken, 1987: 500), og at folk dedikerer mere opmærksomhed til negativ information end til positiv information (Pratto \& John, 1991: 380). Generelt bearbejdes negativ information grundigere end positiv information, og negativ information huskes ofte bedre end positiv information (Robinson-Riegler \& Winton, 1996; Ohira et al., 1998). Undersøgelser af tv-nyheder har vist, at negative billeder og nyheder øger opmærksomheden hos seeren (Soroka \& McAdams, 2015), samtidig med at information i nyheden huskes bedre (Lang et al., 1996: 460). Overordnet set tyder det på, at negative informationer bearbejdes grundigere og derfor huskes bedre end positive informationer, og at det også gør sig gældende for tv-nyheder.

H2: De seere, der har set en negativ nyhed, vil huske mere af historien end de seere, der har set en positiv nyhed.

Trussler og Soroka (2014) har vist, at særligt politisk interesserede har tendens til at efterspørge negative nyheder, også selvom de svarer, at de synes, at nyhederne er for negative og kyniske over for politikere. Alligevel peger flere af forfatterne i bogen "En konstruktiv nyhed" på, at en konsekvens af journalisternes negative fokus kan være, at folk helt vender ryggen til nyhederne ( $\mathrm{fx}$ Gyldensted, 2012; Haagerup, 2012; Knoop, 2012). En del empiri viser da også, at individer stræber efter positive humørtilstande og prøver at undgå negative humørtilstande (Bless \& Fiedler, 2006), idet vi som mennesker angiveligt skulle have udviklet et adfærdsmæssigt og kognitivt repertoire, som hjælper os med at fastholde positive tilstande. (Bless \& Fiedler, 2006: 66-68; Erber \& Markunas, 2006: 254). Hvis negative nyheder medfører negativt humør, vil teorien om humørregulering i sidste ende betyde, at folk vil forsøge at undgå de negative nyheder, hvilket fører til vores sidste forventning.

H3: Negative tv-nyheder mindsker folks lyst til at se nyheder. 


\section{Eksperimentets design}

For at teste vores hypoteser gennemførte vi et eksperiment, hvor tre grupper så hver deres version af den samme nyhedshistorie, henholdsvis det originale indslag, et negativt og et positivt, mens en fjerde gruppe - kontrolgruppen - ikke så noget indslag. Deltagerne blev tilfældigt placeret i de fire grupper. Denne såkaldte randomisering er metodens styrke, fordi den ud fra et tilfældighedsprincip sikrer, at gruppernes sammensætning er så ens, at eventuelle forskelle i humør, hukommelse af informationer og lyst til at se nyheder kun skyldes den varierende positivitet/negativitet i de indslag, de hver især har set, og ikke tredje variabler (Laustsen et al., 2014).

\section{Nyhedsindslagene i eksperimentet}

Det indslag, vi valgte som udgangspunkt for eksperimentet, blev bragt i TV Avisen på DR1 den 10. november 2014 klokken 18.30. Det handlede om, at 75 kommuner havde benyttet sig af et tilbud om at få ansatte på et kursus i at opdage børn, der har været udsat for vold eller seksuelle overgreb, mens 23 kommuner ikke havde sendt medarbejdere på kurset.

Indslaget har flere fordele i forhold til eksperimentets formål. For det første rummer det både positive og negative elementer, så indslaget kan klippes med ekstra fokus på positive eller negative elementer. Det er med andre ord muligt at bevare historiens kerne, blandt andet den samme grundinformation og de samme kilder (se tabel 1), og samtidig variere graden og strukturen af henholdsvis positive og negative elementer. Ved at anvende det samme indslag i forskellige versioner kunne vi holde så mange aspekter som muligt konstante på tværs af grupperne, mens vi alene varierede graden af negativitet/positivitet. Derved kan man mere præcist sige noget om årsag og effekt og styrke den interne validitet (Skovsgaard \& Svith, 2014). 
Tabel 1. Grundinformation i alle tre indslag

- 75 kommuner har haft medarbejdere på efteruddannelse i at opdage børn, der har været udsat for vold eller seksuelle overgreb.

- Struer Kommune har haft 600 medarbejdere på kurset.

- 23 kommuner har valgt ikke at sende medarbejdere på kurset.

- Red Barnet undrer sig over, at ikke alle benytter sig af kursustilbuddet.

- Tønder og Brønderslev har ikke benyttet sig af kursustilbuddet. De har iværksat deres egen efteruddannelse i det samme.

Antallet af underretninger om udsatte børn i Struer Kommune steg fra 13 til 44 efter kurset.

Socialminister Manu Sareen (RV) glæder sig over, at mange kommuner er taget på kursus, men synes, det er ærgerligt, at 23 kommuner ikke har benyttet sig af tilbuddet.

For det andet får man ved at vælge et indslag, som har været bragt i virkeligheden, så realistisk et indslag som muligt. En medarbejder fra DR Nyheder har hjulpet med at redigere og speake indslagene, så de har fået det samme professionelle udtryk som det originale indslag, som han også har indtalt speak til. Således ligner alle tre indslag de tv-nyheder, som deltagerne i eksperimentet ser til daglig. En af de potentielle svagheder ved et eksperiment er den eksterne validitet, altså spørgsmålet om, hvorvidt resultaterne kan generaliseres til, hvad der sker i virkeligheden uden for det kunstige setup, som et eksperiment er. Ved at sikre så realistiske indslag som muligt reducerer man problemer med den eksterne validitet, selvom der naturligvis stadig vil være forskel på at se et indslag som del af en undersøgelse eller se det hjemme i sofaen eller i køkkenet, mens man laver mad (Laustsen et al., 2014: 233-234).

Det er afgørende for eksperimentet at få variation på, hvor positivt eller negativt de forskellige indslag er. Baseret på Gyldensted (2011), som testede fem forskellige måder at ændre en journalistisk historie i positiv retning på, har vi valgt at fokusere på to måder, nemlig peak-end narrative og 3-1 positive ratio. Gylden- 
steds undersøgelse tydede på, at netop disse to er mest effektive i forhold til at påvirke modtagernes humør.

Ifølge peak-end reglen dømmer vi vores oplevelser ud fra, hvordan de var, da de peakede (behagelige eller ubehagelige), og hvordan de endte (Fredrickson \& Kahneman, 1993). Skal man overføre dette princip til en nyhed, så skal den konstrueres, så den har et positiv højdepunkt (peak) cirka halvvejs gennem historien og en positiv slutbemærkning (end). Princippet bag 3-1 positive ratio er, at der skal tre positive følelser til hver negativ følelse, for at et individ trives (Fredrickson \& Losada, 2005).

Baseret på disse to principper blev indslagene klippet om. Uden at ændre på indslagets grundinformation blev der i overensstemmelse med 3-1 positive ratio-princippet skruet op for de positive elementer, såsom løsninger, inspiration og konstruktivitet, og ned for de negative elementer, såsom konflikt, ofre og dramatik, i det positive indslag, mens det omvendte gjorde sig gældende i det negative indslag. Samtidig blev det positive indslag klippet, så det havde et positivt højdepunkt såvel som en positiv slutning, mens det negative indslag havde en negativ slutning og ikke noget positivt højdepunkt. ${ }^{1}$ For at se, om manipulationen af indslagene virkede efter hensigten, blev respondenterne spurgt, hvordan de på en syvpunktsskala fra 0 (meget positivt) til 6 (meget negativt) opfattede det indslag, de havde set. Gruppen, der havde set den positive nyhed, opfattede som forventet indslaget som mere positivt $(\mathrm{M}=2,05 \mathrm{SD}=1,26)$ end de grupper, der så den originale $(\mathrm{M}=3,04 \mathrm{SD}=1,44)$ og den ekstra negative nyhed $(\mathrm{M}=3,20 \mathrm{SD}=1,48)$. Forskellene fra det positive indslag til de to andre er begge statistisk signifikante $(\mathrm{P}<0,001)$. Selvom gruppen, der så den øgede negative udgave af indslaget, opfattede det som mere negativt end gruppen, der så den originale nyhed, var denne forskel ikke statistisk signifikant. Dette kan dog forklares med, at den originale nyhed, som man kunne forvente på baggrund af nyhedernes generelle negative fokus, allerede var temmelig negativt vinklet, og der var grænser for, hvor meget vi kunne manipulere den ekstra negative udgave i negativ retning, hvis den samtidig skulle beholde sin realisme. 


\section{Måling af humør, hukommelse og lyst til at se tv-nyheder}

Målingen af humør tog ligesom hos Gyldensted (2011) udgangspunkt i PANAS-skalaen, som er en valideret skala, der er udviklet til at måle positiv og negativ affekt (Watson \& Clark, 1988). Skalaen består i sin originale form af tyve tilstande, der enten karakteriseres som positive eller negative, men anvendes her i reduceret form for ikke at overbelaste respondenterne. På en fempunkts Likert-skala med svar fra 'slet ikke' til 'i høj grad' blev respondenterne spurgt, i hvor høj grad de følte fire positive følelser (begejstret, stærk, optimistisk og inspireret) og fire negative følelser (nedtrykt, bekymret, irritabel og bange). En faktoranalyse bekræftede, at de otte spørgsmål måler to underliggende dimensioner (positive og negative følelser) frem for en skala, der går fra negativ i den ene ende til positiv i den anden. På baggrund af analysen konstruerede vi to indeks, der går fra et minimum på 0 og et maksimum på 4 for henholdsvis de negative følelser $(\mathrm{M}=1,10 \mathrm{SD}=, 73 \alpha=, 705)$ og positive følelser $(\mathrm{M}=1,50 \mathrm{SD}=, 96$ $\alpha=, 846)$.

Hukommelse blev målt via fire multiple choice-spørgsmål, hvor respondenten skulle huske faktuelle oplysninger fra nyhedsindslaget (se Valkenburg et al., 1999 for et tidligere eksempel på denne fremgangsmåde). Da alle indslag uanset graden af positivitet/negativitet indeholdt de samme grundinformationer, kunne vi stille de samme spørgsmål til alle og undgå, at forskelle i genkaldelse af information skyldtes spørgsmål med forskellige sværhedsgrader. Vi konstruerede en skala for hukommelse af information ved at give et point for hvert rigtigt svar og lægge pointene sammen ${ }^{2}$. Skalaen går således fra et minimum på 0 til et maksimum på $4(\mathrm{M}=3,31 \mathrm{SD}=, 78)$.

Lysten til at se tv-nyheder blev målt via spørgsmålet: I hvor høj grad har du på nuvcerende tidspunkt lyst til at se (flere) tv-nyheder? Spørgsmålet skulle besvares på en fempunktsskala, som gik fra 'slet ikke' (0) til 'i meget høj grad' (4) (M=1,69 SD=1,11).

\section{Deltagere i undersøgelsen}

Når man undersøger sit forskningsspørgsmål med et eksperiment, er den væsentligste pointe i forhold til deltagerne, at de 
skal inddeles tilfældigt i de forskellige grupper, som i dette tilfælde ser forskellige indslag. Det er mindre væsentligt, at deltagerne er tilfældigt udvalgt, da de ikke nødvendigvis behøver at være repræsentative for den generelle befolkning, fordi vi er interesseret i de forskelle, der opstår på baggrund af de forskellige tv-indslag, og ikke i at identificere selve niveauet af humør, hukommelse eller lyst til at se tv-nyheder (for en diskussion se Druckman \& Kam, 2011). Deltagerne i denne undersøgelse er fundet på to måder. Dels er der blevet indsamlet mailadresser gennem personlig kontakt, hvor respondenter er blevet inviteret til at deltage i undersøgelsen, og dels er undersøgelsen delt på Facebook af de to forfattere. Selvom vores deltagere således ikke er repræsentative for befolkningen, er der en vis spredning $\mathrm{i}$ både alder (M=35 SD=12,49), køn (62 \% kvinder), og om respondenterne selv har børn, hvilket kan tænkes at påvirke identifikationen i forhold til indslaget, der handler om børn, der udsættes for overgreb (47 \% har børn). Derudover ville vi gerne undgå at have journalister eller journaliststuderende blandt vores respondenter, da de på grundlag af deres journalistiske uddannelse kan være skolet $\mathrm{i}$ at have præferencer for negative nyheder. Derfor undlod vi at invitere journalister eller journaliststuderende til undersøgelsen. Samtidig spurgte vi som det første respondenterne, hvorvidt de var journalister eller journaliststuderende, så vi kunne sende dem, der svarede bekræftende, ud af undersøgelsen med det samme.

Respondenterne blev i undersøgelsen inddelt i forskellige grupper efter et tilfældighedsprincip. Dette blev gjort ved at spørge respondenterne, hvilken dag på måneden de har fødselsdag, og derefter blev de delt ind i grupperne 'originalt indslag' (1.-8.), 'positivt indslag' (9.-16.), 'negativt indslag' (17.-23.) og 'kontrolgruppen' (24.-31.). En test af randomiseringen viste ingen statistisk signifikante forskelle mellem grupperne i forhold til alder, køn, og om respondenterne har børn eller ej.

En anden udfordring i forbindelse med eksperimenter er, hvis respondenterne gennemskuer formålet med undersøgelsen og svarer enten det, de tror, forskeren gerne vil have, eller det modsatte af, hvad forskeren gerne vil have (Laustsen et al., 2014). For at undgå dette fik respondenterne blot at vide, at undersøgelsen handlede om tv-nyheder, og at de skulle se et indslag og svare på 
nogle spørgsmål. En væsentlig pointe er, at hver respondent kun så et indslag (bortset fra kontrolgruppen, der ikke så noget indslag) og derfor under alle omstændigheder ville have svært ved at gennemskue undersøgelsens formål, nemlig at sammenligne reaktionen på forskellige klipninger af det samme indslag.

\section{Analyse}

For at undersøge vores første hypoteser om respondenternes humør sammenligner vi humøret for de grupper, der har set henholdsvis den positive, den originale og den negative udgave af indslaget samt kontrolgruppen, der ikke har set noget indslag. Selvom gruppen, der har set det positive indslag, ligger lidt højere på skalaen for det positive humør end de grupper, der har set det originale og det negative indslag, er denne forskel minimal, og den er ikke statistisk signifikant (se figur 1). Analysen støtter altså ikke hypotese $1 a \mathrm{om}$, at en positiv nyhed vil resultere i mere positivt humør end en negativ nyhed.

Figur 1. Positivt humør fordelt på grupper, der har set forskellige indslag

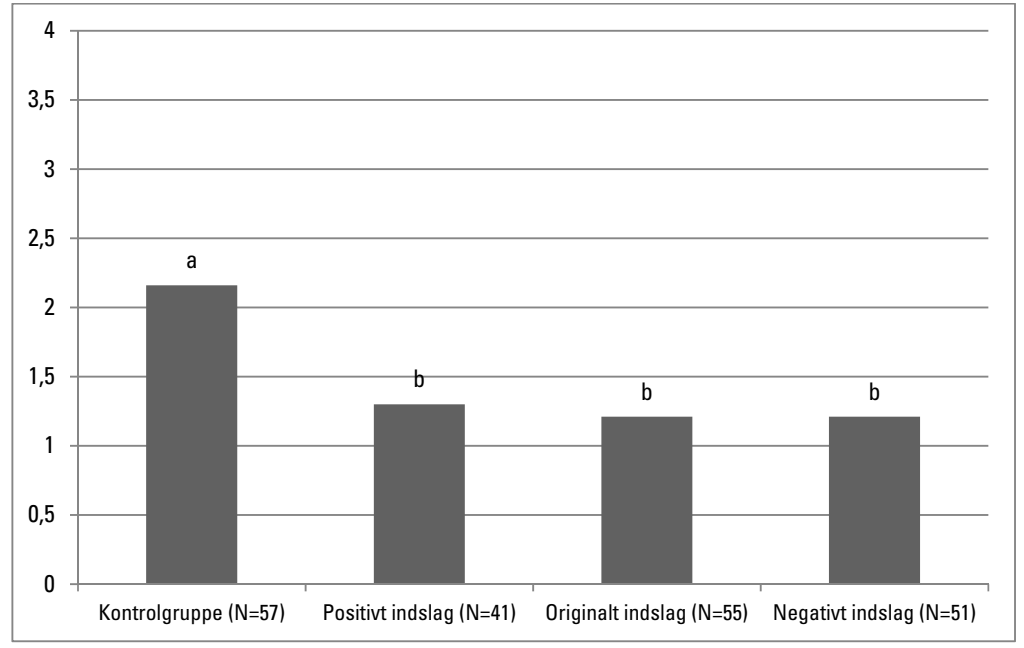

Forskellige bogstaver betyder, at forskellen mellem grupperne er statistisk signifikant på $\mathrm{p}<, 05$ niveau 
Figur 2. Negativt humør fordelt på grupper, der har set forskellige indslag

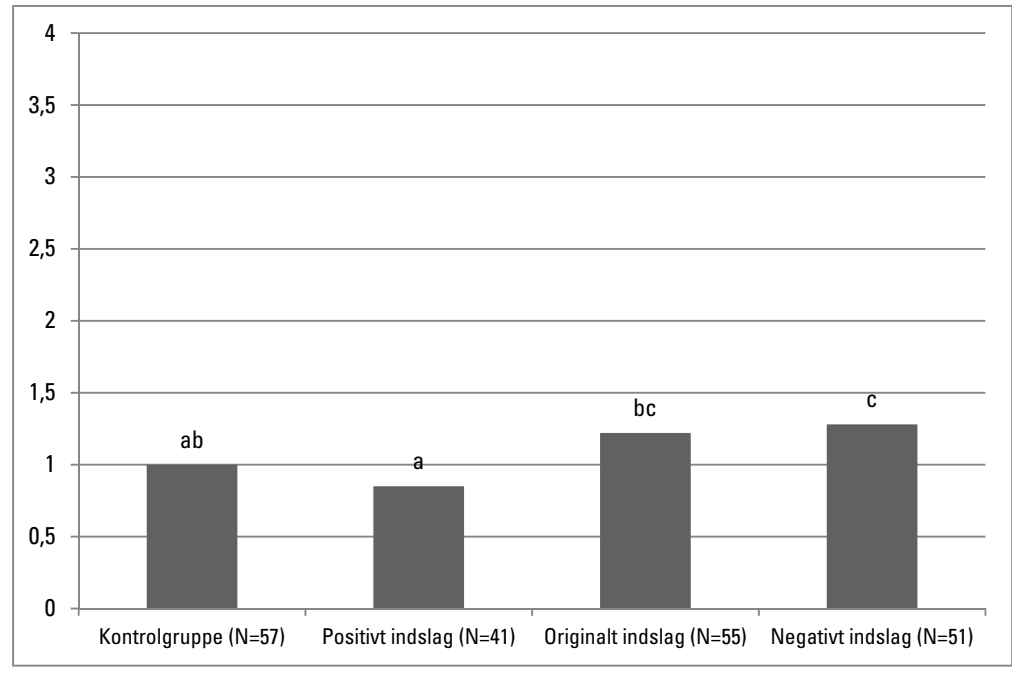

Forskellige bogstaver betyder, at forskellen mellem grupperne er statistisk signifikant på $\mathrm{p}<, 05$ niveau

Når det kommer til det negative humør, er der derimod statistisk signifikante forskelle (se figur 2). Gruppen, som så den positive udgave af indslaget, scorer i gennemsnit 0,85 på skalaen over negativt humør, mens grupperne, der så den originale udgave og den negative udgave, scorer henholdsvis $1,22(\mathrm{t}(94)=2,390$, $\mathrm{p}=, 019)$ og $1,28(\mathrm{t}(90)=3,181, \mathrm{p}=, 002)$ (begge $\mathrm{t}$-tests er i sammenligning med gruppen, der så det positive indslag). Resultaterne viser altså, at et negativt indslag resulterer i mere negativt humør end et positivt indslag, og en nærmere analyse af de forskellige følelser viser, at især bekymringen stiger. Dermed støtter analysen hypotese $1 b$.

Det siger dog ikke noget om, hvorvidt en negativ nyhed har større effekt på humøret end en positiv nyhed, da det både kan være det positive indslag, der sænker graden af negativt humør, mens det også kan være det originale og det negative indslag, der øger graden af det negative humør. Derfor må vi inddrage kontrolgruppen, som ikke har set et indslag, da den er et udtryk for, hvordan humøret er i udgangspunktet.

I den sammenligning bliver det tydeligt, at det positive humør reduceres, når man ser et nyhedsindslag om at opdage, om børn 
udsættes for overgreb. Det gælder, uanset om indslaget fokuserer på de positive eller de negative aspekter af emnet. Mens kontrolgruppen, der ikke så noget indslag, scorer 2,16 på skalaen for det positive humør, scorer de øvrige grupper mellem 1,21 og 1,30. Altså en markant og klart statistisk signifikant forskel i det positive humør for dem, der har set, og dem, der ikke har set, indslaget. Samtidig fører det negative indslag ikke til mindre positivt humør end det positive indslag, og derfor støtter denne del af analysen ikke vores hypotese $1 c \mathrm{om}$, at negative nyheder påvirker humøret mere end positive.

For det negative humør er billedet anderledes. Kontrolgruppen scorer 1,00 på det negative humør, mens gruppen, der så det positive indslag, scorer lavere på negativt humør $(0,85)$. Selvom resultatet er i den forventede retning, er det ikke statistisk signifikant forskelligt fra resultatet i kontrolgruppen $(\mathrm{t}(96)=1,054$, $\mathrm{p}=$,294). Det samme gælder for gruppen, der så det originale indslag. Til trods for at den i gennemsnit scorer 1,22 på skalaen for det negative humør, og resultatet er i den forventede retning, er forskellen til kontrolgruppen ikke statistisk signifikant $(\mathrm{t}(110)=1,482, \mathrm{p}=, 141)$. Anderledes er det for gruppen, der så det negative indslag. Den scorer 1,28 og har dermed en signifikant højere grad af negativt humør end kontrolgruppen $(\mathrm{t}(106)=2,106$, $\mathrm{p}=, 038$ ). Det betyder altså, at det negative indslag har større effekt på det negative humør end det positive indslag, og dermed støtter denne del af analysen hypotese $1 c$.

I forbindelse med analysen er det værd at hæfte sig ved, at resultaterne for grupperne, der så henholdsvis det originale og det negative indslag, ikke adskiller sig væsentligt fra hinanden i forhold til både det positive og negative humør. Det er i overensstemmelse med, at det originale indslag ligesom det negative indslag blev opfattet temmelig negativt af respondenterne i vores test af stimulusmaterialet, hvilket støtter ideen om en generel tendens til et negativt fokus i journalistikken.

Næste spørgsmål handler om, hvorvidt indslagets positive eller negative fokus har betydning for den information, seerne kan huske fra indslaget. Som det fremgår af figur 3, er der kun minimale forskelle på, hvor meget respondenterne i de forskellige grupper husker fra indslaget. Ingen af forskellene er statistisk signifikante, hvilket betyder, at graden af positive/negative 
aspekter i indslaget ikke umiddelbart har nogen indflydelse på, hvor mange informationer respondenterne husker fra indslaget. Dermed støtter analysen ikke hypotese 2 om, at et negativt indslag ville betyde, at informationen ville blive bearbejdet grundigere og dermed husket bedre.

Figur 3. Hukommelse af information fordelt på grupper, der har set forskellige indslag

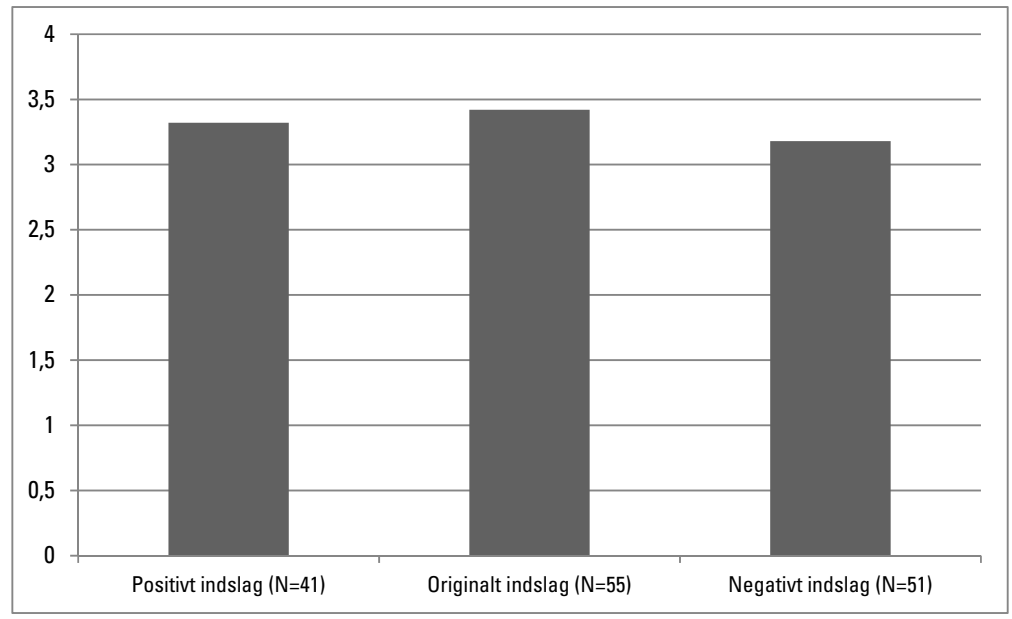

Ingen signifikante forskelle mellem grupperne ved $p<, 05$ niveau

Det sidste spørgsmål handler om, hvorvidt positive og negative nyheder også påvirker folks lyst til at se nyheder. En af bekymringerne omkring det negative fokus i nyhederne er netop risikoen for, at folk vender ryggen til nyhederne (fx Haagerup, 2012). Som det fremgår af figur 4, er der i denne undersøgelse dog stort set ingen forskel mellem de forskellige grupper i forhold til at have lyst til at se tv-nyheder, og ingen af forskellene er i nærheden af at være statistisk signifikante. Dermed støtter analysen ikke umiddelbart hypotese $3 \mathrm{om}$, at negative nyheder mindsker folks lyst til at se tv. 
Figur 4. Lyst til at se tv-nyheder fordelt på grupper, der har set forskellige indslag

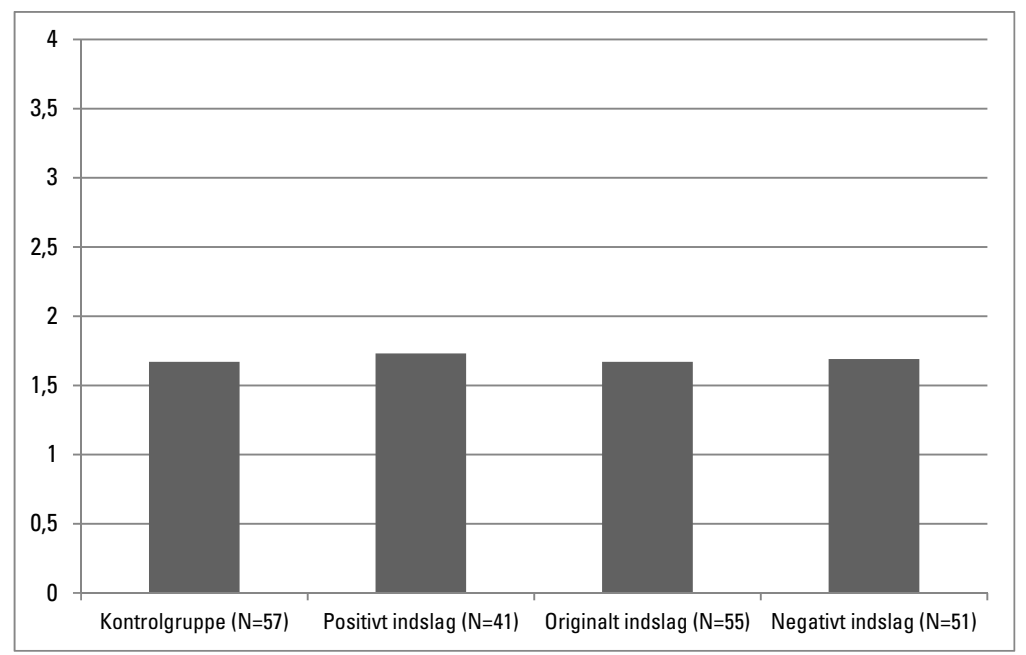

Ingen signifikante forskelle mellem grupperne ved $p<, 05$ niveau

\section{Diskussion}

Denne undersøgelse er et skridt på vejen mod mere viden om effekterne af henholdsvis negative og positive nyheder. Via et eksperimentelt design, hvor vi har vist forskellige grupper mere eller mindre positive/negative udgaver af det samme nyhedsindslag, kan vi påvise, at det gør en forskel på seernes humør, om en nyhed fokuserer på positive eller negative aspekter, og at det negative indslag påvirker humøret mere end det positive. Samtidig huskede de respondenter, der havde set den negative udgave af indslaget, mod vores forventning ikke mere end dem, der havde set den positive udgave. De negative nyheders positive indflydelse på hukommelsen kunne være et argument for at holde fast i et udpræget negativt fokus, men denne gavnlige effekt kunne vi altså ikke påvise i vores undersøgelse. En mulig forklaring er, at folk er så vant til at se negative nyheder, at de ikke længere skiller sig ud, og deres påvirkningskraft er blevet mindre i forhold til positive nyheder. Dette begreb er blevet kaldt desensetizing (Scharrer, 2008) og er også blevet påvist i en hollandsk undersøgelse, hvor folk ikke fik flere fordomme af negative historier om indvandrere, mens positive historier førte til færre 
fordomme (Boomgarden, 2007). En anden mulig forklaring er, at spørgsmålene, hvor respondenterne skal genkalde sig informationen fra indslagene, er for lette. I hvert fald husker respondenterne i gennemsnit 3,31 informationer ud af fire mulige, og ni ud af ti respondenter har tre eller fire korrekte svar ud af fire mulige. Den lave variation kan tyde på, at selv med begrænset opmærksomhed på indslaget er det muligt at huske de fleste af de fire efterspurgte informationer. Der er derfor brug for yderligere undersøgelser af dette spørgsmål, inden man kan drage stærke konklusioner. Samtidig er det væsentligt at understrege, at selv hvis negative nyheder viser sig at have den positive effekt, at folk husker dem bedre, har negative nyheder stadig andre negative konsekvenser som eksempelvis påvirkningen af humøret eller eksempelvis en øget økonomisk pessimisme (Soroka, 2006).

Selvom de negative og positive forslag påvirkede seernes humør, fandt vi ingen forskelle i lysten til at se yderligere tv-nyheder hos dem, der havde set forskellige indslag. Således kan vi ikke umiddelbart bekræfte frygten for, at de negative nyheder vil få folk til at vende ryggen til nyhederne. Som en del af undersøgelsen gav vi dog også deltagerne mulighed for at uddybe deres svar, og nogle af disse svar kan nære frygten for, at folk på længere sigt vil vende ryggen til nyhederne på grund af negativiteten. Flere respondenter pegede nemlig på det negative fokus:

" Jeg er generelt træt af, at der i tv-nyheder bliver sat meget negativ fokus på nyhederne. En mere positiv tilgang til denne nyhed kunne jo have været, at der var flere, der havde taget imod tilbuddet, end der ikke havde ..." (Kvinde, 26 år, negativt indslag).

"Der er ikke nok gode nyheder i tv. Tragedie og brok tiltrækker de savlende masser!" (Mand, 28 år, kontrolgruppen).

"Nyheder er ofte negative, dårlige. Skræmmende. Samtidig er jeg nødt til at forholde mig til verden omkring mig, derfor ser jeg kun nyheder ca. én gang dagligt." (Kvinde, 60 år, kontrolgruppen).

Disse kommentarer kan pege i retning af, at et negativt fokus over tid kan få folk til at vende ryggen til nyhederne. Man skal dog tage forbehold for, at der er tale om udtalelser fra et mindre 
antal respondenter, og folk har tendens til at vælge mere negative nyheder end dem, de selv siger, at de har præference for (Trussler \& Soroka, 2014), og derfor være forsigtig med fortolkningen. Det er da også netop den akkumulerede effekt af et vedvarende negativt fokus, der er svær at undersøge i et eksperiment, som bygger på forskelle genereret af et enkelt tv-indslag. I den virkelige verden ser man flere indslag ad gangen i en nyhedsudsendelse, og mange ser flere nyhedsudsendelser om ugen. Dermed kan effekten af den samlede sum af negativt fokuserede nyhedsindslag godt have konsekvenser for folks lyst til at se tv-nyheder, selvom vi ikke kan dokumentere effekten i denne undersøgelse. Det modsatte kan dog også gøre sig gældende. Mens man i et eksperiment kun ser et eller et meget begrænset antal indslag, vil man i en nyhedsudsendelse se adskillige. Selvom der sandsynligvis vil være overvægt af negativt vinklede indslag, vil der som regel også være positivt vinklede indslag imellem. Det er uklart, hvad denne blanding af indslag med forskellige grader af positivitet og negativitet samlet set betyder for effekterne af de enkelte indslag, men noget forskning viser, at forskellige frames i nogle situationer udligner hinanden (Chong \& Druckman, 2013).

Samtidig skal man holde sig for øje, at denne undersøgelse begrænser sig til at undersøge tre mulige effekter af positive kontra negative nyheder, nemlig humør, lyst til at se nyheder og hukommelse af information i indslaget. En vigtig del af journalistikkens rolle i samfundet er at fungere som samfundets vagthund, som kontrollerer magthaverne ved at påpege uregelmæssigheder, problemer, magtmisbrug og konfliktlinjer (fx Graber, 2003; McQuail, 2005). Denne funktion skal være med til at sikre et velfungerende demokrati, hvor de repræsentanter, folket har valgt, eller de embedsmænd, der skal implementere de folkevalgtes beslutninger, holder sig inden for gældende regler og normer og lever op til borgernes forventninger. Dette afspejler sig også i journalisternes rolleopfattelser, hvor den kritiske vagthund er det dominerende og mest konsistente ideal på tværs af forskellige typer journalister (Skovsgaard et al., 2012). Derved er et negativt fokus i et eller andet omfang uundgåeligt og samtidig også ønskeligt, da det kan have en afskrækkende effekt på magthavere, som overvejer at bryde regler eller normer. Det er i den sammenhæng væsentligt at understrege, at denne artikel ikke 
argumenterer for, at positivt vinklede nyheder skal erstatte de mere negative nyheder, men at det er vigtigt at være bevidst om de mulige effekter, positive som negative, af henholdsvis negative og positive nyheder.

\section{SLUTNOTER}

1 Den fulde udskrift af indslagene kan rekvireres hos forfatterne.

2 De fire spørgsmål var (det korrekte svar markeret med fed skrift):

Spørgsmål 1: "Struer kommune er en af de kommuner, hvor medarbejderne har været på kursus arrangeret af staten. Hvor mange medarbejdere har de haft af sted på kurset?

Svarmuligheder: 1) 300 medarbejdere 2) 400 medarbejdere 3) 500 medarbejdere 4) 600 medarbejdere”.

Spørgsmål 2: "Hvad skete der i Struer Kommune, umiddelbart efter deres medarbejdere havde været på kurset?

Svarmuligheder: 1) Antallet af underretninger om udsatte børn i kommunen faldt 2) Antallet af underretninger om udsatte børn i kommunen steg 3) Antallet af underretninger om udsatte børn i kommunen forblev nærmest uændret”.

Spørgsmål 3: "I nyhedsindslaget møder vi to af de kommuner, der har fravalgt kurset arrangeret af staten. Hvilke kommuner er der tale om? Svarmuligheder: 1) Brønderslev og Skanderborg 2) Aalborg og Tønder 3) Skanderborg og Aalborg 4) Tønder og Brønderslev".

Spørgsmål 4 ”Hvad er årsagen til, at de to kommuner har fravalgt statens kursus?

Svarmuligheder: 1) De havde ikke råd til at sende medarbejderne på kurset 2) De synes ikke, at de tidligere havde haft problemer med at opdage udsatte børn, og fandt derfor ikke kurset relevant 3) De havde allerede selv iværksat initiativer, der skulle lære medarbejderne de samme ting, som statens kursus skulle lære dem". 


\section{REFERENCER}

Baum, M. A. \& Groeling, T. J. (2010). War stories: the causes and consequenses of public views of war. Princeton: Princeton University Press. Baumeister, R. F., Bratlavsky, E., Finkennauerm, C og Vohs, K. D. (2001). "Bad Is Stronger Than Good", Review of General Psychology, vol. 5, no. 4, pp. 323-370.

Bless, H. \& Fiedler, K. (2006). "Mood and the Regulation of Information Processing and Behavior", pp. 65-85 i J. P. Forgas (red.) Affect in Social Thinking and Behavior. New York: Psychology Press.

Boomgarden, H. (2007). Framing the Others: News and Ethnic Predjudice. Upubliceret ph.d.-afhandling, Amsterdam Universitet.

Chong, D. \& Druckman, J. N. (2013). “Counterframing Effects”, Journal of Politics, vol. 75, no. 1, pp. 1-16.

Elmelund-Præstekær, C. \& Svensson, H. M. (2013). "Negativ og personfokuseret kampagneretorik: Partiernes kommunikation og mediernes dækning ved folketingsvalg 1994-2011", Politica, vol. 45, no. 4, pp. 481-502 .

Erber, R. \& Markunas, S. (2006). ”Managing Affective States” pp. 252-267 i J. P. Forgas (red.) Affect in Social Thinking and Behavior. New York: Psychology Press.

Fallows J. (1996). Breaking the News: How the Media Undermine American Democracy. New York: Pantheon Books.

Fredrickson, B. L., \& Kahneman, D. (1993). "Duration neglect in retrospective evaluations of affective episodes”, Journal of Personality \& Social Psychology, vol. 65, no. 1, pp. 45-55.

Fredrickson, B. \& Losada, M. (2005). "Positive Affect and the Complex Dynamics of Human Flourishing”, American Psychologist, vol. 60, no. 7, pp. 678-686.

Graber, D. (2003). “The Media and Democracy: Beyond Myths and Stereotypes”, Annual Review of Political Science, vol. 6, pp. 139-160.

Gyldensted, C. (2011). "Innovating News Journalism through Positive Psychology”, Master-afhandling, Positive Psychology Center: Pennsylvania (http://repository.upenn.edu/cgi/viewcontent. cgi?article=1024\&context=mapp_capstone besøgt 14. december 2015).

Gyldensted, C. (2012). "Spøgelset fra Watergate - Nixon ud af nyhederne” pp. 185-196 i U. Haagerup (red.): En konstruktiv nyhed. Aarhus: Forlaget Ajour.

Haagerup, U. (2012). En konstruktiv nyhed: Et opgør med pressens negative verdenssyn. Aarhus: Forlaget Ajour.

Hede, A., Goul Andersen, J. \& Andersen, J. (2009). Tryghedsmåling 2009: 
Danskernes tryghed på verdenskrisens og bandekrigenes tid. Trygfonden (tilgængelig på: http://www.e-pages.dk/trygfonden/65/ besøgt 14. december 2015).

Hylleberg, R., Rasmussen, C. S., Byrdal, L., Mortensen, M. B. \& Haslund, A. (2012). "Positiv - Negativ Journalistik. En kvantitativ indholdsanalyse”. Speciale, RUC (http://rudar.ruc.dk/handle/1800/8523 besøgt 14. december 2015).

Kabel, L. (2005). Verden langt herfra. Aarhus: Center for Journalistik og Efteruddannelse.

Knoop, H. H. (2012). "Mediernes negative fokus påvirker folkestemningen”, pp. 59-73 i U. Haagerup (red.): En konstruktiv nyhed. Aarhus: Forlaget Ajour.

Lang, A., Newhagen, J. \& Reeves, B. (1996). "Negative video as structure: Emotion, attention, capacity, and memory", Journal of Broadcasting \& Electronic Media, vol. 40, no. 4, pp. 460-477.

Laustsen, L., Hopmann, D. N. \& Slothuus, R. (2014). “Eksperimenter", pp. 221-235 i D. N. Hopmann \& M. Skovsgaard (red.) Forskningsmetoder i journalistik og politisk kommunikation. København: Hans Reitzels Forlag.

McQuail, D. (2005). Mass Communication Theory (5th edition). London: Sage Publications.

Meyerowitz, B. E. \& Chaiken, S. (1987). "The effect of Message Framing on Breast Self-Examination attitudes, intentions, and behaviour", Journal of Personality and Social Psychology, vol. 52, no. 3, pp. 500-510.

Newhagen, J. E. \& Reeves, B. (1992). “The Evening's Bad News: Effects of Compelling Negative Television Images on Memory", Journal of Communication, vol. 42, no. 2, pp. 25-41.

Ohira, H., Winton, W. M. \& Oyama, M. (1998). "Effects of stimulus valence on recognition memory and endogenous eyeblinks: Further evidence for positive-negative asymmetry", Personality and Social Psychology Bulletin, vol. 24, no. 9, pp. 986-993.

Patterson, T. E. (1994). Out of Order. New York: Vintage.

Peterson, C. \& Steen, T. A. (2009). “Optimistic Explanatory Style” in S. J. Lopez \& C.R Snyder (red.) The Oxford Handbook of Positive Psychology (2. edition). Oxford: Oxford University Press.

Pratto, F. \& John, O.P. (1991). "Automatic vigilance: The attention-grabbing power of negative social information", Journal of Personality and Social Psychology, vol. 61, no. 3, pp. 380-391.

Reeves, B., Lang, A., Thorson, E. \& Rothschild, M. (1989). “Emotional Tel- 
evision Scenes and Hemispheric Specialization", Human Communication Research, vol. 15, no. 4, pp. 493-508.

Robinson-Riegler, G. L. \& Winton, W. M. (1996). “The role of conscious recollection in recognition of affective material: Evidence for positive-negative asymmetry”, Journal of General Psychology, vol. 123, no. 2, pp. 93-104.

Sabato, L. (1991). Feeding Frenzy: How Attack Journalism Has Transformed American Politics. New York: Free Press.

Scharrer, E. (2008). "Media exposure and sensitivity to violence in news reports: Evidence of desensitization?”, Journalism \& Mass Communication Quarterly, vol. 85, no. 2, pp. 291-310.

Skovsgaard, M., Albæk, E., Bro, P. \& de Vreese, C. (2012). "Media Professionals or Organizational Marionettes?”, pp. 155-170 i Weaver, D. \& Willnat, L. (red.) The Global Journalist in the 21st Century. Routledge, New York.

Skovsgaard, M. \& Svith, F. (2014). "Validitet og reliabilitet”, pp. 61-85 i D. N. Hopmann \& M. Skovsgaard (red.) Forskningsmetoder i journalistik og politisk kommunikation. København: Hans Reitzels Forlag.

Soroka, S. N. (2006). “Good News and Bad News: Asymmetric Responses to Economic Information”, The Journal of Politics, vol. 68, no. 2, pp. 372-385.

Soroka, S. (2014). Negativity in Democratic Politics. Causes and Consequences. Cambridge: Cambridge University Press.

Soroka, S. \& McAdams, S. (2015). “News, Politics, and Negativity”, Political Communication, vol. 32, no. 1, pp. 1-22.

Trussler, M. \& Soroka, S. (2014). "Consumer Demand for Cynical and Negative News Frames”, The International Journal of Press/Politics vol. 19, no. 3, pp. 360-379.

Valkenburg, P. M., Semetko, H. A. \& de Vreese, C. H. (1999). “The Effects of News Frames on Readers' Thoughts and Recall”, Communication Research. vol. 26, no. 5, pp. 550-569.

Watson, D. \& Clark, L. A. (1988). "Development and Validation of Brief Measures of Positive and Negative affect: The PANAS Scales”, Journal of Personality and Social Psychology, vol. 54, no. 6, pp. 1062-1070.'

Weaver, D. \& Willnat L. (red.) (2012). The Global Journalist in the 21st Century. Routledge, New York. 


\section{FORFATTERE}

Morten Skovsgaard

Lektor ved Center for Journalistik, Syddansk Universitet

skh@sam.sdu.dk

Pernille Frantz Søberg

Cand. Public. fra Syddansk Universitet

pernille.frantz@gmail.com 


\title{
Get the blues from the news
}

\author{
The effect of positive and negative television news on \\ viewers' mood, recollection and inclination to watch \\ additional news
}

\section{BY MORTEN SKOVSGAARD AND PERNILLE FRANTZ SøBERG}

The debate on the negative focus in the news and its potential consequences has for several years been intense. Some fear that it will ultimately result in more and more citizens turning their backs on news content. However, the knowledge of the effects of positive and negative news reports is limited. Drawing on a survey experiment, this article studies how a positive and a negative focus in television news reports affect the moods of the viewers, their recollection of information in the news report, and their inclination to watch additional news reports. We presented three randomized groups with either an original news report, or the same news report edited in order to have a more positive or a more negative focus. A fourth group served as our control group. The results show that people who watched a news report with a negative focus reported to be in significantly worse mood than not only those who watched a news report with a positive focus but also those who did not watch a news report. The study shows no effects of a positive versus a negative focus when it comes to the recollection of information from the news report or the inclination to watch additional news reports. 